University of Nebraska - Lincoln

DigitalCommons@University of Nebraska - Lincoln

USDA National Wildlife Research Center - Staff Publications
U.S. Department of Agriculture: Animal and Plant Health Inspection Service

January 2006

\title{
A Simple HPLC Method for the Determination of Chlorpyrifos in Black Oil Sunflower Seeds
}

Richard E. Mauldin

U.S. Department of Agriculture, Animal and Plant Health Inspection Service, Wildlife Services, National Wildlife Research Center

Thomas M. Primus

U.S. Department of Agriculture, Animal and Plant Health Inspection Service, Wildlife Services, National Wildlife Research Center

Theresa A. Buettgenbach

U.S. Department of Agriculture, Animal and Plant Health Inspection Service, Wildlife Services, National Wildlife Research Center

John J. Johnston

U.S. Department of Agriculture, Animal and Plant Health Inspection Service, Wildlife Services, National Wildlife Research Center

G. M. Linz

USDA/APHIS/WS National Wildlife Research Center, george_m_linz@yahoo.com

Follow this and additional works at: https://digitalcommons.unl.edu/icwdm_usdanwrc

Part of the Environmental Sciences Commons

Mauldin, Richard E.; Primus, Thomas M.; Buettgenbach, Theresa A.; Johnston, John J.; and Linz, G. M., "A Simple HPLC Method for the Determination of Chlorpyrifos in Black Oil Sunflower Seeds " (2006). USDA National Wildlife Research Center - Staff Publications. 424.

https://digitalcommons.unl.edu/icwdm_usdanwrc/424

This Article is brought to you for free and open access by the U.S. Department of Agriculture: Animal and Plant Health Inspection Service at DigitalCommons@University of Nebraska - Lincoln. It has been accepted for inclusion in USDA National Wildlife Research Center - Staff Publications by an authorized administrator of DigitalCommons@University of Nebraska - Lincoln. 


\title{
A Simple HPLC Method for the Determination of Chlorpyrifos in Black Oil Sunflower Seeds
}

\author{
Richard E. Mauldin, Thomas M. Primus, \\ Theresa A. Buettgenbach, and John J. Johnston
}

U.S. Department of Agriculture, Animal and Plant Health Inspection Service, Wildlife Services, National Wildlife Research Center,

Fort Collins, Colorado, USA

\section{George M. Linz}

U.S. Department of Agriculture, Animal and Plant Health Inspection Service, Wildlife Services, National Wildlife Research Center, Bismarck, North Dakota, USA

\begin{abstract}
Damage to ripening sunflowers by blackbirds is an important agricultural problem in the northern Great Plains. In an effort to reduce crop loss by non-lethal means, several insecticidal formulations were evaluated for potential bird repellency. One formulation, Lorsban ${ }^{\circledR}-4 \mathrm{E}$, was highly effective in feeding studies with caged blackbirds. Chlorpyrifos (an organophosphate pesticide) is a registered insecticide and acaricide commonly used to control insects on sunflower, and is the active ingredient in Lorsban ${ }^{\circledR}-4 \mathrm{E}$. To support further evaluation of chlorpyrifos repellency in field trials, a rapid, simple, high performance liquid chromatographic (HPLC) analytical method was developed to assess residues in sunflower seeds, which had been aerially sprayed. Control black oil sunflower seeds were cryopulverized, fortified with chlorpyrifos at $0.50 \mu \mathrm{g} \cdot \mathrm{g}^{-1}, 5.0 \mu \mathrm{g} \cdot \mathrm{g}^{-1}, 50 \mu \mathrm{g} \cdot \mathrm{g}-1$, and $500 \mu \mathrm{g} \cdot \mathrm{g}^{-1}$, and extracted in $90 \%$ acetonitrile/10\% $1 \mathrm{mM}$ phosphate buffer ( $\mathrm{pH} 4.5)$. Extracts were filtered and analyzed by reverse phase HPLC with UV detection at $230 \mathrm{~nm}$, with one elution method for samples ranging from $5.00 \mu \mathrm{g} \cdot \mathrm{g}^{-1}$ chlorpyrifos to $500 \mu \mathrm{g} \cdot \mathrm{g}^{-1}$ chlorpyrifos, and a second elution method for samples ranging from $0.500 \mu \mathrm{g} \cdot \mathrm{g}^{-1}$
\end{abstract}

Address correspondence to Richard E. Mauldin, Analytical Chemistry Project, USDA/APHIS/WS/National Wildlife Research Center, 4101 LaPorte Ave., Fort Collins, CO 80521, USA. E-mail: richard.e.mauldin@aphis.usda.gov 
chlorpyrifos to $<5.00 \mu \mathrm{g} \cdot \mathrm{g}^{-1}$ chlorpyrifos. The methods were rugged and reliable, with chlorpyrifos recovery $>95 \%$ for all fortified concentrations. The method limit of detection was $0.328 \mu \mathrm{g} \cdot \mathrm{g}^{-1}$ and $0.221 \mu \mathrm{g} \cdot \mathrm{g}^{-1}$ chlorpyrifos for Methods 1 and 2, respectively, and no chromatographic interferences were observed with either method.

Keywords: Sunflower, Blackbirds, Chlorpyrifos, CAS\# 2921-88-2, Lorsban ${ }^{\circledR}-4 \mathrm{e}$, High performance liquid chromatography, HPLC

\section{INTRODUCTION}

In the tri-state region of the northern Great Plains states (North Dakota and South Dakota, Minnesota) production of sunflowers has increased from a few thousand acres in the early 1960's to over 3.5 million acres currently, ${ }^{[1]}$ accounting for over $90 \%$ of the cultivated sunflower crop in the United States, ${ }^{[2]}$ and yielding a crop value of over 350 million US dollars annually.

Ripening of the sunflower crop in late August-early September coincides with the beginning of the annual southerly migration of many bird species from Canada, along migration routes that funnel millions of birds through the tri-state region. The presence of ripening sunflower seeds offers a highly nutritious, easily obtainable food resource for foraging flocks of birds, especially blackbirds. Migratory flocks of red-winged blackbirds (Agelaius phoeniceus), yellow-headed blackbirds (Xanthocephalus xanthocephalus), and common grackles (Quiscalus quiscula) form night roosts in cattail (Typha spp.) dominated wetlands that can number $>100,000$ individuals. The close proximity of potentially large numbers of blackbirds to the ripening sunflower crops presents an enormous opportunity for crop loss.

Over the last twenty years, scientists from the National Wildlife Research Center (NWRC) and North Dakota State University have extensively investigated a wide variety of lethal and non-lethal strategies to deter birds from feeding on sunflower seeds. Non-lethal methods have included habitat manipulation (opening up marshes by removing cattails and minimizing attraction to blackbirds), hazing with aircraft, frightening devices such as propane cannons and pop-up scarecrows, and development and propagation of bird-resistant sunflower varieties. ${ }^{[3]}$ Planting of adjacent fields containing alternative food crops have also been employed. ${ }^{[4]}$ While occasionally effective, none of these methods yield the overall protection required by large scale sunflower growers. Lethal methods, such as the use of avicidetreated baits, can be effective in some situations but negative public response and potential environmental risks limit their use.

Interest has grown into the application of chemical repellents to minimize seed depredation by birds. Currently, only one product, Bird Shield ${ }^{\circledR}$ (active ingredient: methyl anthranilate), is registered for use in ripening sunflower, 
but has shown little efficacy with blackbirds. ${ }^{[5]}$ Anecdotally, biologists have observed that following application of some fungicides and insecticides, bird foraging in the treated areas was reduced. NWRC biologists screened a number of insecticides currently registered for use in sunflowers to determine if any would exhibit repellency to red-winged blackbirds in cage trials. ${ }^{[6]}$ Birds were presented with either control (untreated) seeds or seeds treated with one of five insecticidal formulations at the highest label rate recommended for that formulation. One formulation, Lorsban ${ }^{\circledR}-4 E$ (Dow AgroSciences Canada LLC, Calgary, Alberta) reduced seed consumption by $82 \%$ when compared with the consumption of birds fed untreated seeds. Further testing showed effective Lorsban $^{\circledR}-4 \mathrm{E}$ repellency at half the maximum label rate.

The active ingredient in Lorsban ${ }^{\circledR}-4 \mathrm{E}$ is chlorpyrifos (CAS\# 2921-88-2), a registered insecticide and acaricide. Chlorpyrifos is an organophosphate pesticide used widely around the world, and is currently registered with the U.S. EPA as an insecticide in a wide variety of crops, including sunflowers. The primary degradant of chlorpyrifos is 3,5,6-trichloro-2-pyridinol, a base hydrolysis product. Concentrations of chlorpyrifos, which resulted in repellency in caged feeding trials, were approximately $507 \mathrm{mg}$ active ingredient/ $\mathrm{kg}$ of sunflower seeds (full rate) and $254 \mathrm{mg}$ active ingredient $/ \mathrm{kg}$ of sunflower seeds (half rate).

Further investigation into the repellency of chlorpyrifos under standard agricultural conditions, involves the aerial spraying of chlorpyrifos onto field-grown sunflower plants in open cages, and measurement of subsequent seed loss to birds introduced into the cages following the application. It will be necessary to measure actual incurred residues on both control and treated plots to assess the concentrations actually found on the seeds. To support this work, the Analytical Chemistry Project at the NWRC has developed a simple extraction method requiring no sample cleanup, followed by HPLC analysis of the sunflower seed extract.

For most foodstuffs, chlorpyrifos analysis is usually carried out using gas chromatography (GC) with flame photometric detection or nitrogen phosphorous detection. ${ }^{[7-9]}$ However, high sample lipid content virtually requires extensive sample cleanup to remove fats and oils ${ }^{[7]}$ when GC is used. Black oil sunflower seeds contain an oil content of approximately $40 \%$ by weight, depending on growing conditions and the sunflower cultivar used. ${ }^{[10]}$ Due to the exploratory nature of the current study and the comparatively high chlorpyrifos concentrations expected, fast sample throughput, ease of extraction, and minimal sample cleanup were of greater importance than detection sensitivity. High performance liquid chromatography (HPLC) has been used previously for chlorpyrifos determination in oranges, ${ }^{[11]}$ as well as leaves and soil. ${ }^{[12]}$ We have adapted the method of Gaurdino et al. to analyze pulverized, extracted sunflower seeds for chlorpyrifos, and present two sets of HPLC analysis conditions, the second set added to improve the sensitivity and overall usability of the method. 


\section{EXPERIMENTAL}

\section{Sample Preparation}

Due the frequency and ubiquity of chlorpyrifos application in the U.S. and Canada for a wide variety of crops, control black oil sunflower seeds were obtained from Viejo Roble International S.A. Buenos Aires, Argentina. A $10 \mathrm{~g}-30 \mathrm{~g}$ aliquot of seeds was cryogenically pulverized using a freezer mill (SPEX Certiprep, Model 6850 , Metuchen, New Jersey). One gram of homogenized sunflower seeds was accurately weighed into a $50 \mathrm{~mL}$ screw top glass vial, followed by the addition of $5.0 \mathrm{~mL}$ of a premixed solution of $90 \%$ acetonitrile $/ 10 \% 1 \mathrm{mM} \mathrm{PO} 4$ buffer ( $\mathrm{pH} 4.5)$. The sample was then mixed gently by hand, sonicated for $10 \mathrm{~min}$, vortex mixed, then placed in a mechanical shaker (Eberbach Equalpoise, Ann Arbor, MI) and shaken at high speed for $15 \mathrm{~min}$. The sample was centrifuged at approximately $2000 \mathrm{rpm}$ for $5 \mathrm{~min}$, and the supernatant was removed and transferred to a $10 \mathrm{~mL}$ tube. A second $5.0 \mathrm{~mL}$ of the premixed solvent was added to the original sample, and the extraction procedure repeated. As much as possible of the first $5 \mathrm{~mL}$ extract was carefully transferred back into the original sample tube, which was then vortex mixed and centrifuged. The complete supernatant was transferred back to the $10 \mathrm{~mL}$ tube, which had held the first extract, and mixed thoroughly. An aliquot of the extract was filtered through a $0.45 \mu \mathrm{m}$ teflon syringe filter into an amber HPLC vial.

\section{Chromatographic Conditions}

Extracts were analyzed using an 1100 series HPLC (Agilent Co., Sunnyvale, CA) equipped with a UV/Vis detector (UV at $230 \mathrm{~nm}$ ). A Phenomenex (Torrance, CA) Prodigy ODS $/ 3, \mathrm{C}_{18}, 5 \mu \mathrm{m}, 250 \mathrm{~mm} \times 4.6 \mathrm{~mm}$ i.d. analytical column was used, along with a Phenomenex SecurityGuard guard column $\left(4 \mathrm{~mm} \times 2 \mathrm{~mm}, \mathrm{C}_{18}\right)$. Extracts were chromatographed with a pre-mixed mobile phase comprised of $75 \%$ acetonitrile $/ 25 \% 1 \mathrm{mM} \mathrm{PO}_{4}(\mathrm{pH} 4.5)$ at room temperature. Two separate methods were used to elute the analyte depending on the level of sensitivity required.

\section{Method 1}

Injection of $25 \mu \mathrm{L}$ at a flow rate of $1 \mathrm{~mL} \cdot \min ^{-1}$ for $25 \mathrm{~min}\left(5.0 \mu \mathrm{g} \cdot \mathrm{g}^{-1}\right.$, $50 \mu \mathrm{g} \cdot \mathrm{g}^{-1}$, and $500 \mu \mathrm{g} \cdot \mathrm{g}^{-1}$.

\section{Method 2}

Injection, of $100 \mu \mathrm{L}$ at a flow rate of $1 \mathrm{~mL} \cdot \mathrm{min}^{-1}$ for $17 \mathrm{~min}$, increase flow rate to $2.5 \mathrm{~mL} \cdot \mathrm{min}^{-1}$ for $13 \mathrm{~min}$, decrease flow to $1 \mathrm{~mL} \cdot \mathrm{min}^{-1}$ for two min to stabilize flow $\left(0.500 \mu \mathrm{g} \cdot \mathrm{g}^{-1}\right)$. 


\section{Selectivity, Bias, and Repeatability, and Method Limit of Detection (MLOD)}

Method validation was performed on whole black oil sunflower seeds, which had been cryogenically pulverized to a fine powder. Three sets of seven $1.0 \mathrm{~g}$ replicates were fortified at one of three chlorpyrifos concentrations: i) $500 \mu \mathrm{g} \cdot \mathrm{g}^{-1}$, ii) $50 \mu \mathrm{g} \cdot \mathrm{g}^{-1}$, and iii) $5 \mu \mathrm{g} \cdot \mathrm{g}^{-1}$, using $0.050 \mathrm{~mL}$ of a $10.00 \mu \mathrm{g} \cdot \mathrm{mL}^{-1}, \quad 1.00 \mu \mathrm{g} \cdot \mathrm{mL}^{-1}$, or a $0.100 \mu \mathrm{g} \cdot \mathrm{mL}^{-1}$ standard solution of chlorpyrifos in acetonitrile, respectively. Samples were immediately vortex-mixed, allowed to stand for 15 minutes, extracted as previously described, and analyzed using the chromatographic procedure described in Method 1. A fourth set of six $1.0 \mathrm{~g}$ sample replicates were fortified at $0.500 \mu \mathrm{g} \cdot \mathrm{g}^{-1}$ using $0.050 \mathrm{~mL}$ of a $0.0100 \mu \mathrm{g} \cdot \mathrm{mL}^{-1}$ chlorpyrifos standard in acetonitrile. Following the procedure described previously, these replicates were analyzed using the chromatographic procedure described in Method 2. Seven control sunflower seed replicates were also prepared, fortified with $0.050 \mathrm{~mL}$ of acetonitrile, extracted as described, and analyzed using the chromatographic procedures in Method 1. Five of the control sunflower seed replicates fortified with $0.050 \mathrm{~mL}$ of acetonitrile were analyzed using the procedure described in Method 2.

The MLOD was defined as the chlorpyrifos concentration required to generate a chromatographic response $3 \times$ the baseline noise (measured peakto-peak) found in control sunflower seeds at the retention time of chlorpyrifos.

Seven replicates of control sunflower seed tissue and seven replicates of control tissue fortified to a concentration of $5.0 \mu \mathrm{g} \cdot \mathrm{g}^{-1}$ chlorpyrifos, were used to assess the MLOD of Method 1, and five replicates of control sunflower seed tissue and six replicates of control tissue fortified to a concentration of $0.500 \mu \mathrm{g} \cdot \mathrm{g}^{-1}$ chlorpyrifos, were used to evaluate the MLOD for Method 2.

\section{RESULTS AND DISCUSSION}

\section{Linearity}

\section{Method 1}

A linear regression analysis was performed on the chromatographic response data $^{[13]}$ generated using Method 1. A set of 10 chlorpyrifos standard solutions ranging in concentration from $500 \mu \mathrm{g} / \mathrm{mL}$ to $0.01 \mu \mathrm{g} / \mathrm{mL}$ were analyzed in triplicate, and the chromatographic data used to assess linearity. Regression analysis yielded an $\mathrm{r}^{2}$ of 0.9999 , a y-intercept of $11.17398( \pm 13.80762)$ (HO: $y_{\text {int }}=0, p=0.4252$ ), and a slope of 46.65297. The coefficient of variation $(\mathrm{CV})$ of response factors (chlorpyrifos concentration divided by chromatographic response) was $3.33 \%$. A $\log$ vs. log plot of these data yielded an $r^{2}$ of 0.9999 and a slope of 0.99135 . Taken together, these 


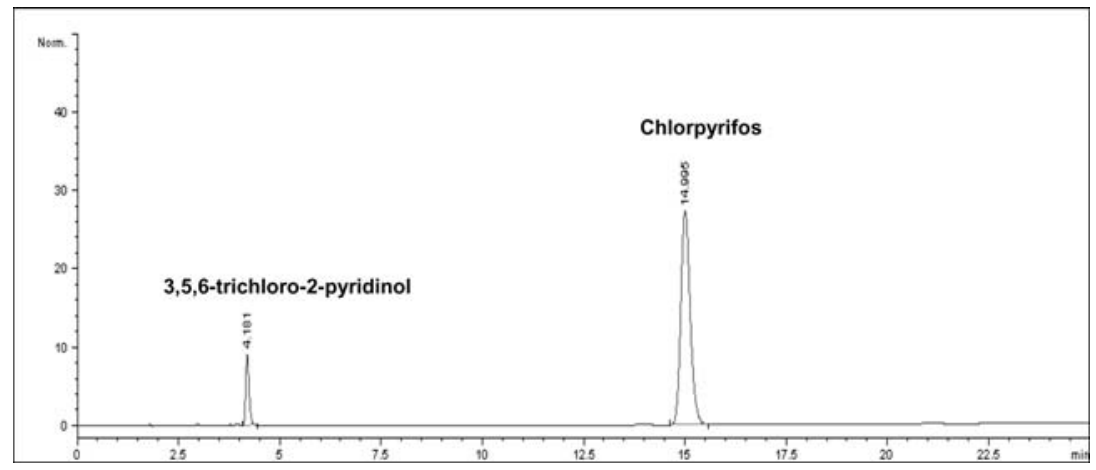

Figure 1. Chromatogram of the $10.0 \mu \mathrm{g} \cdot \mathrm{mL}^{-1}$ working chlorpyrifos standard and a $10.0 \mu \mathrm{g} \cdot \mathrm{mL}^{-1}$ 3,5,6-trichloro-2-pyridinol standard.

results indicated a highly linear and proportional relationship between chlorpyrifos concentration and chromatographic response, and justified the use of a single point calibration standard $\left(10.0 \mu \mathrm{g} \cdot \mathrm{mL}^{-1}\right)$. A chromatogram of the $10.0 \mu \mathrm{g} \cdot \mathrm{mL}^{-1}$ working standard and a $10.0 \mu \mathrm{g} \cdot \mathrm{mL}^{-1}$ 3,5,6-trichloro-2pyridinol standard to demonstrate the separation of these compounds is illustrated in Figure 1.

\section{Method 2}

A linear regression analysis was performed on the chromatographic response data generated using Method 2. A set of 5 chlorpyrifos standard solutions ranging in concentration from $0.500 \mu \mathrm{g} / \mathrm{mL}$ to $0.025 \mu \mathrm{g} / \mathrm{mL}$ were analyzed in triplicate, and the chromatographic data used to assess linearity. Regression analysis yielded an $\mathrm{r}^{2}$ of 0.9998 , a y-intercept of 0.39908 $( \pm 0.19105)\left(\mathrm{HO}: \mathrm{y}_{\mathrm{int}}=0, \mathrm{p}=0.0 .0570\right)$, and a slope of 193.2611. The coefficient of variation $(\mathrm{CV})$ of response factors (chlorpyrifos concentration

Table 1. Percent recoveries from chlorpyrifos-fortified control powdered sunflower seeds. Values in parentheses are one standard deviation

\begin{tabular}{ll}
\hline Chlorpyrifos $\left(\mu \mathrm{g} \cdot \mathrm{g}^{-1}\right)$ & Recovery $(\%)$ \\
\hline Method 1 & \\
500 & $95.3( \pm 4.1)$ \\
50.0 & $95.5( \pm 0.99)$ \\
5.00 & $95.5( \pm 0.87$ \\
Method 2 & \\
0.500 & $113( \pm 5.9)$ \\
\hline
\end{tabular}


divided by chromatographic response) was 3.66\%. A log vs. log plot of these data yielded an $r^{2}$ of 0.9994 and a slope of 0.97666 . Taken together, these results indicated a highly linear and proportional relationship between chlorpyrifos concentration and chromatographic response, and justified the use of a single point calibration standard $\left(0.050 \mu \mathrm{g} \cdot \mathrm{mL}^{-1}\right)$.

\section{Selectivity, Bias, Repeatability, and MLOD}

Chlorpyrifos recoveries for the $500 \mu \mathrm{g} \cdot \mathrm{g}^{-1}, 50.0 \mu \mathrm{g} \cdot \mathrm{g}^{-1}, 5.00 \mu \mathrm{g} \cdot \mathrm{g}^{-1}$, and $0.500 \mu \mathrm{g} \cdot \mathrm{g}^{-1}$ concentrations of fortified powdered black oil sunflower seeds using Methods 1 and 2 are given in Table 1.

Recoveries exceeded $95 \%$ for all fortification levels, and standard deviations were $\leq 6 \%$ in all cases. Chromatograms of a control sunflower seed extract and an extract of control sunflower seed fortified to $5 \mu \mathrm{g} \cdot \mathrm{g}^{-1}$ chlorpyrifos, both analyzed using Method 1, are illustrated in Figure 2A and 2B, respectively.
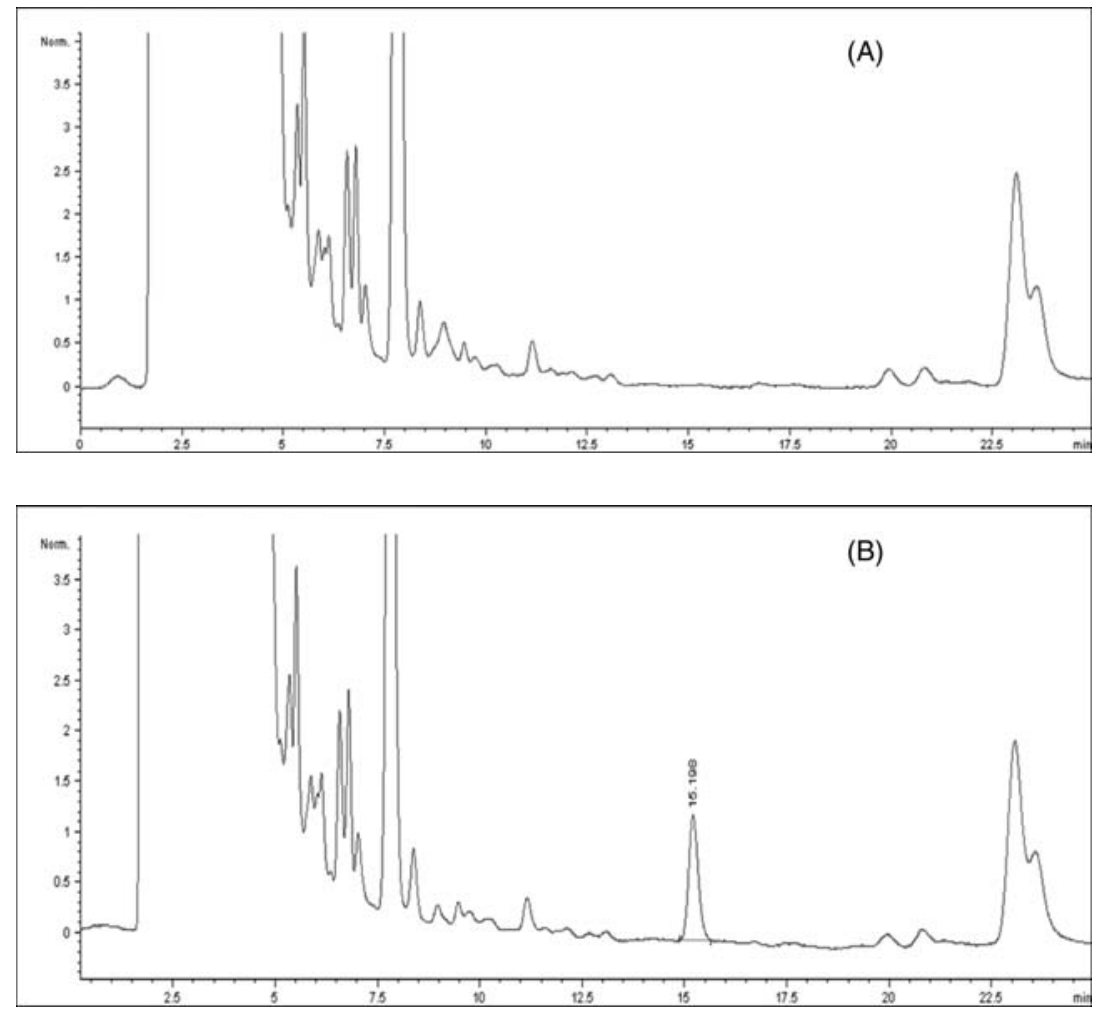

Figure 2. (A) Chromatogram of control sunflower seed extract analyzed using Method 1. (B) Chromatogram of extract of control sunflower seed fortified to $5.0 \mu \mathrm{g} \cdot \mathrm{g}^{-1}$ chlorpyrifos analyzed using Method 1 . 
Chromatograms of a control sunflower seed extract and an extract of control sunflower seed fortified to $0.50 \mu \mathrm{g} \cdot \mathrm{g}^{-1}$ chlorpyrifos, both analyzed using Method 2, are illustrated in Figure 3A and 3B, respectively. No interferences were noted at the retention time of chlorpyrifos in any sample using either Method 1 or 2 . The MLODs for Methods 1 and 2 were $0.328 \mu \mathrm{g} \cdot \mathrm{g}^{-1}$ and $0.221 \mu \mathrm{g} \cdot \mathrm{g}^{-1}$, respectively.

\section{General}

Initially, powdered sunflower seeds were extracted in a $75 \%$ acetonitrile $/ 25 \%$ $10 \mathrm{mM} \mathrm{PO}_{4}$ buffer, but an increase in acetonitrile to $90 \%$ both improved the chlorpyrifos extraction efficiency and required a decrease in the molarity of the phosphate buffer to $1 \mathrm{mM}$ to minimize the risk of salting out the phosphate buffer. Percentages of water in the extraction solvent higher than $25 \%$ initiated the formation of emulsions. The use of two $5 \mathrm{~mL}$ extractions
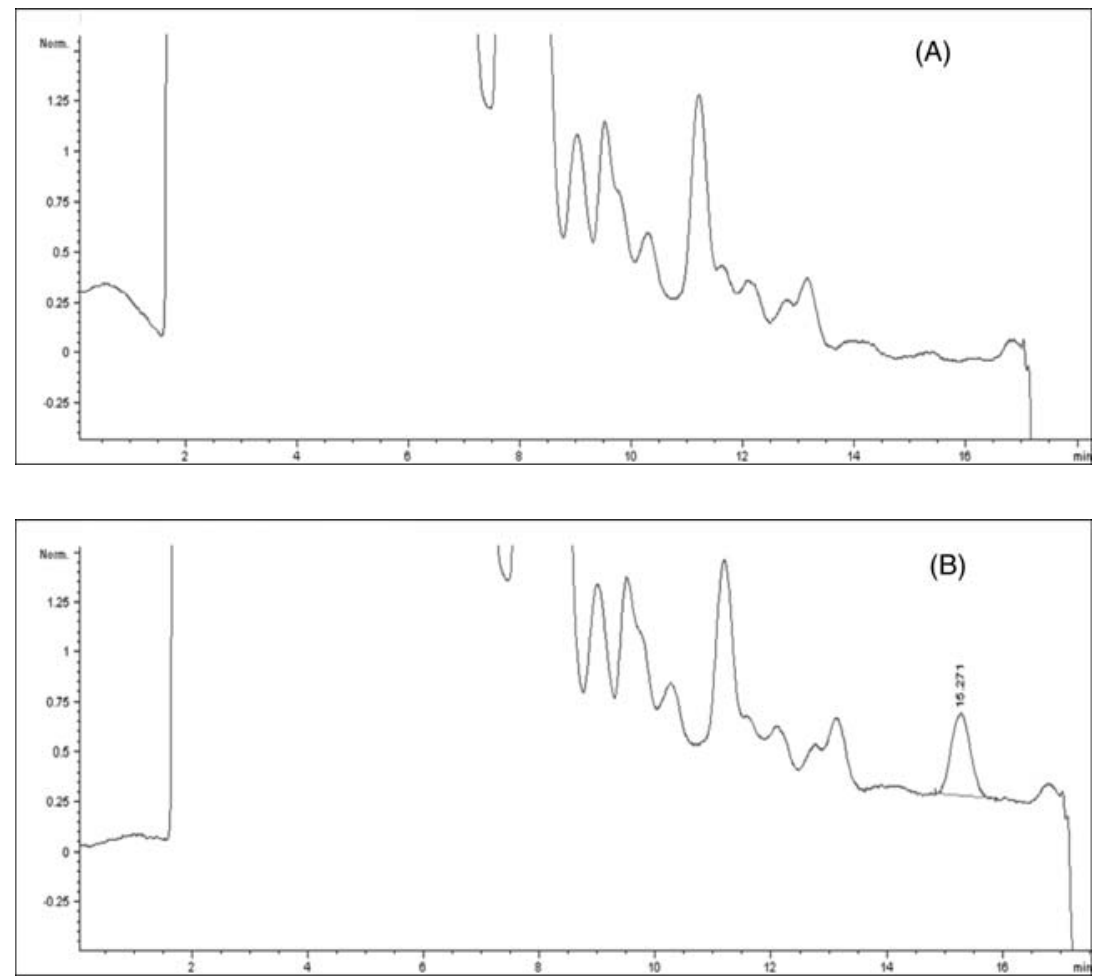

Figure 3. (A) Chromatogram of control sunflower seed extract analyzed using Method 2. (B) Chromatogram of extract of control sunflower seed fortified to $0.50 \mu \mathrm{g} \cdot \mathrm{g}^{-1}$ chlorpyrifos analyzed using Method 2 . 
provided substantially better recoveries than one $10 \mathrm{~mL}$ extraction. As stated, the removal and subsequent addition of the first extract back to the extraction tube was carefully and thoroughly done. While this is not the usual practice, the dilution incurred by bringing the extract to a set volume was deemed undesirable. The final volume was assumed to be $10.0 \mathrm{~mL}$, and method validation data did not indicate any systematic error by the use of this assumption.

The only substantive difference between Methods 1 and 2 was the sample injection volume ( $25 \mu \mathrm{L}$ vs. $100 \mu \mathrm{L}$, respectively). The increase in flow rate following analyte elution in Method 2 was simply to allow small, postanalyte peaks, which had become apparent following the increased injection volume to elute prior to the next analysis.

In summary, we have developed a simple, quick method for the extraction and subsequent HPLC analysis of chlorpyrifos in black oil sunflower seeds. The method is rugged, reliable, and the addition of a second set of HPLC conditions allows an additional order of magnitude in sensitivity.

\section{DISCLAIMER}

Use of a trade name does not constitute endorsement by the U.S. government.

\section{ACKNOWLEDGMENT}

The authors would like to thank Donald Wille of Archer Daniels Midland Company for his invaluable assistance in procuring true control sunflower seeds.

\section{REFERENCES}

1. Linz, G.M.; Kenyon, M.J.; Barras, A.E.; Knutsen, G.A.; Homan, H.J.; Bergman, D.L.; Huffman, L.E.; Bleier, W.J. Progress on reducing blackbird damage to sunflower: status of avicide research. Sunflower Research Workshop sponsored by the National Sunflower Association, 1997; 110-111.

2. Schaaf, D.; Linz, G.M.; Bleier, W.J.; Homan, H.J. Avian use of ripening sunflower fields. Proc. of the 23rd Sunflower Res. Workshop, Jan. 17-18, 1997; 177-178.

3. Linz, G.M.; Hanzel, J.J. Birds and Sunflower. In Sunflower Technology and Production; Agronomy Monograph no. 35; American Society of Agronomy, Crop Sci. Soc. of America, Soil Sci., Soc. of America: Madison, WI, 1997.

4. Hagy, H.M.; Raetzman, J.M.; Linz, G.M.; Bleier, W.J. Decoy cropping methods for luring blackbirds away from commercial sunflower: USDA wildlife conservation sunflower plots. Wildlife Damage Management Conference, Traverse City, Michigan, May 16-19, 2005.

5. Werner, S.J.; Homan, H.J.; Avery, M.L.; Linz, G.M.; Tilman, E.A.; Slowik, A.A.; Byrd, R.W.; Primus, T.M.; Goodall, M.J. Evaluation of Bird Shield ${ }^{\mathrm{TM}}$ as a 
blackbird repellent in ripening rice and sunflower fields. Wildlife Soc. Bull. 2005, 33 (1), 251-257.

6. Linz, G.M.; Slowik, A.A.; Penry, L.B.; Homan, H.J. Evaluation of Lorsban ${ }^{\circledR}-4$ E aerially sprayed on sunflower plots for bird repellency. Sunflower Research Forum, January 12-13, 2004, Fargo, N.D. 1-4; NSA Website Online Forum, www.sunflowernsa.com/research.

7. Serrano, R.; Lopez, F.J.; Roig-Navarro, A.; Hernandez, F. Automated sample clean-up and fractionation of chlorpyrifos, chlorpyrifos-methyl, and metabolites in mussels using normal-phase liquid chromatography. J. Chromatogr. A 1997, $778,151-165$.

8. Helrich, K. Method 985.22 gas chromatography method. Organochlorine and organophosphorous pesticide residues. In Official Methods of the Association of Official Analytical Chemistry, 15th Ed.; Assocation of Analytical Chemistry, Inc.: Arlington, VA, 1990; 282-283.

9. Their, H-P; Zeumer, H. Organochlorine, organophosphorous, nitrogen-containing and other compounds. Method S19. In Manual of Pesticide Residue Analysis; Their, H-P, Zeumer, H., Eds.; Deutsche Forschugsgemeinschaft, VCH Publishers: New York, 1987; Vol. 1, 383-400.

10. National Sunflower Association. In U.S. Sunflower Crop Quality Report, 2004. http://www.sunflowernsa.com/uploads/cqr/cqr2004.pdf.

11. Yamazaki, Y.; Ninomiya, T. Determination of benomyl, diphenyl,o-phenylphenol, thiabendazole, chlorpyrifos, methidathion, and methyl parathion in oranges by solid-phase extraction, liquid chromatography, and gas chromatography. J.A.O.A.C. 1999, 82 (6), 1474-1478.

12. Guardino, X.; Obiols, J.; Rosell, M.G.; Farran, A.; Serra, C. Determination of chlorpyrifos in air, leaves, and soil from a greenhouse by gas-chromatography with nitrogen-phosphorous detection, high performance liquid chromatography, and capillary electrophoresis. J. Chromatogr. A 1998, 823, 91-96.

13. SAS Institute Inc. In SAS/STAT User's Guide; Version 6, 4th Ed.; SAS Institute Inc.: Cary, NC, 1989; Vol. 1, 943.

Received October 4, 2005

Accepted October 31, 2005

Manuscript 6719 